\title{
Carbon monoxide of vascular origin attenuates the sensitivity of renal arterial vessels to vasoconstrictors
}

\author{
Jun-Ichi Kaide, Fan Zhang, Yuan Wei, Houli Jiang, Changhua Yu, WenHui Wang, \\ Michael Balazy, Nader G. Abraham, and Alberto Nasjletti
}

Department of Pharmacology, New York Medical College, Valhalla, New York, USA

Address correspondence to: Jun-Ichi Kaide, New York Medical College, Department of Pharmacology, Valhalla, New York 10595, USA. Phone: (914) 594-4137; Fax: (914) 347-4956; E-mail: Jun-Ichi_Kaide@nymc.edu.

Received for publication August 31, 2000, and accepted in revised form February 26, 2001.

Rat renal interlobar arteries express heme oxygenase 2 (HO-2) and manufacture carbon monoxide (CO), which is released into the headspace gas. CO release falls to $30 \%$ and $54 \%$ of control, respectively, after inhibition of $\mathrm{HO}$ activity with chromium mesoporphyrin (CrMP) or of HO-2 expression with antisense oligodeoxynucleotides (HO-2 AS-ODN). Patch-clamp studies revealed that CrMP decreases the open probability of a tetraethylammonium-sensitive (TEA-sensitive) $105 \mathrm{pS} \mathrm{K}$ channel in interlobar artery smooth muscle cells, and that this effect of CrMP is reversed by CO. Assessment of phenylephrineinduced tension development revealed reduction of the $\mathrm{EC}_{50}$ in vessels treated with $\mathrm{HO}-2 \mathrm{AS}-\mathrm{ODN}$, CrMP, or TEA. Exogenous $\mathrm{CO}$ greatly minimized the sensitizing effect on agonist-induced contractions of agents that decrease vascular $\mathrm{CO}$ production, but not the sensitizing effect of $\mathrm{K}$ channel blockade with TEA. Collectively, these data suggest that vascular CO serves as an inhibitory modulator of vascular reactivity to vasoconstrictors via a mechanism that involves a TEA-sensitive $\mathrm{K}$ channel.

J. Clin. Invest. 107:1163-1171 (2001).

\section{Introduction}

Heme oxygenase 1 (HO-1) and HO-2 metabolize heme to biliverdin, free iron, and carbon monoxide (CO) $(1$, $2)$. HO-2 is constitutively expressed in most tissues, whereas HO- 1 is inducible (1). Products of heme metabolism by $\mathrm{HO}$ possess biological activities that influence vascular function. Biliverdin and its metabolic product bilirubin are antioxidants (3). Free iron facilitates production of reactive oxygen species (3). CO stimulates soluble guanylate cyclase $(4,5)$ and calcium-activated potassium $\left(\mathrm{K}_{\mathrm{Ca}}\right)$ channels $(6)$ in vascular smooth muscle and inhibits expression of endothelin-1 and PDGF in endothelial cells (7).

Arterial vessels express HO-1 and/or HO-2 (8-10). Interventions that alter the expression or activity of vascular $\mathrm{HO}$ bring about changes of vascular tone and/or reactivity. For example, inhibitors of $\mathrm{HO}$ produce constriction of pressurized rat gracilis muscle arterioles (10). On the other hand, heme elicits HO-dependent dilation of rat gracilis muscle arterioles (11), and conditions that induce vascular HO-1 reduce the responsiveness of the rat tail artery and aorta to constrictor agents $(9,12,13)$. It would appear, then, that one or more products of heme metabolism by $\mathrm{HO}$ contribute to vasodilatory mechanisms $(2,9)$.

The present study was designed to test the hypothesis that the reactivity of small arterial vessels to constrictor agonists is tonically inhibited by $\mathrm{CO}$ of vascular origin, via a mechanism that involves upregulation of $\mathrm{K}_{\mathrm{Ca}}$ channel activity in vascular smooth muscle. We con- ducted experiments in rat renal interlobar arteries (a) to quantify the generation of $\mathrm{CO}$ and determine whether it is HO-dependent, (b) to examine the effect of interventions that decrease the activity or expression of $\mathrm{HO}$ on vascular smooth muscle reactivity to constrictor agonists, and (c) to determine the involvement of $\mathrm{K}_{\mathrm{Ca}}$ channels in the action of $\mathrm{CO}$ on the reactivity of vascular smooth muscle to constrictor agonists.

\section{Methods}

Animals. All animal protocols were approved by the Institutional Animal Care and Use Committee of New York Medical College. Male Sprague-Dawley rats (250-300 g; Charles River, Wilmington, Massachusetts, USA) were anesthetized (pentobarbital sodium, 60 $\mathrm{mg} / \mathrm{kg}$, intraperitoneally) and the kidneys were removed and placed on a dish filled with ice-cold Krebs' buffer (composition in mmol/l: $118.5 \mathrm{NaCl}, 4.7 \mathrm{KCl}$, $2.5 \mathrm{CaCl}_{2}, 1.2 \mathrm{KH}_{2} \mathrm{PO}_{4}, 1.2 \mathrm{MgSO}_{4}, 25.0 \mathrm{NaHCO}_{3}$, and 11.1 dextrose). The kidneys were sectioned sagittally and the interlobar arteries were dissected out for use in studies on vascular contractility, recording of $\mathrm{K}^{+}$currents in vascular smooth muscle cells, and assessment of $\mathrm{HO}$ expression and $\mathrm{CO}$ production.

Vascular contractility studies. Renal interlobar arteries with an internal diameter averaging $240 \pm 4 \mu \mathrm{m}$ were cut into ring segments $2 \mathrm{~mm}$ in length. Freshly prepared rings or rings pretreated as described below were mounted on $25 \mu \mathrm{m}$ stainless steel wires in the chambers of a multivessel myograph (J.P. Trading, Aarhus, 
Denmark) for measurement of isometric tension (14). The vessels were bathed in Krebs' buffer containing the nitric oxide synthase inhibitor $N^{\omega}$-nitro-L-arginine methylester (L-NAME; $1 \mathrm{mmol} / \mathrm{l}$ ), unless indicated otherwise, to avoid potential interactions between the nitric oxide and CO systems (15). The buffer was maintained at $37^{\circ} \mathrm{C}$ and was gassed with $95 \% \mathrm{O}_{2}$ and $5 \%$ $\mathrm{CO}_{2}$. After an equilibration period (30-60 minutes), the vascular rings were stretched radially so that the internal circumference was equivalent to $90 \%$ of that the vessel would have if relaxed under a transmural pressure of $80 \mathrm{mmHg}$ (14). Isometric tension was monitored continuously and is expressed as millinewtons per millimeter vessel length $(\mathrm{mN} / \mathrm{mm})$.

Experiments were initiated by exposing the vessels to Krebs' buffer modified by increasing the concentration of $\mathrm{KCl}$ to $60 \mathrm{mmol} / \mathrm{l}$ (by equimolar exchange with $\mathrm{NaCl}$ ), to ascertain reproducibility of contractile responses. Subsequently, the vessels were washed with regular Krebs' buffer and allowed to rest for 30 minutes before beginning construction of concentrationresponse curves to phenylephrine $\left(10^{-9}\right.$ to $5 \times 10^{-5}$ $\mathrm{mol} / \mathrm{l})$, vasopressin $\left(10^{-11}\right.$ to $\left.10^{-7} \mathrm{~mol} / \mathrm{l}\right)$ or KCL $\left(10^{-3}\right.$ to $\left.10^{-1} \mathrm{~mol} / \mathrm{l}\right)$ in accordance with protocols described below. Only one agonist was used in each vascular preparation. Concentration-response curves were constructed by increasing the concentration of agonist every 2 minutes and recording the resulting changes in tension at the end of the 2-minute period.

Protocol 1 investigates the effect of antisense oligodeoxynucleotides that interfere with $\mathrm{HO}$ expression on vascular responsiveness to constrictor agonists. Antisense oligodeoxynucleotides complementary to rat HO-1 mRNA (HO-1 AS-ODN) and rat HO-2 mRNA (HO-2 AS-ODN), as well as the corresponding scrambled oligodeoxynucleotides (HO-1 S-ODN and HO-2 S-ODN), were synthesized by Genosys Biotechnologies Inc. (Woodland, Texas, USA); each oligodeoxynucleotide was phosphorothioated on the first three bases of the $3^{\prime}$ end and was purified by high pressure liquid chromatography. The sequence of HO-1 AS-ODN is 5'-GGCGCTCCATCGCGGGACTG-3' and targets bases +10 to -9 of HO- 1 mRNA, and the sequence of HO-2 AS-ODN is $5^{\prime}$-TCTGAAGACATTGTTGCTGA- $3^{\prime}$ and targets bases +11 to -9 of HO-2 mRNA. The sequence of HO-1 S-ODN is $5^{\prime}$ TCCAGCGGCGTCAGCGGTGC- $3^{\prime}$, and the sequence of HO-2 S-ODN is $5^{\prime}$-GATCTGACTTCAAGTGATTG- ${ }^{\prime}$. The effectiveness of HO-1 AS-ODN and HO-2 AS-ODN to reduce tissue expression of $\mathrm{HO}-1$ and $\mathrm{HO}-2$, respectively, was documented previously (16).

The oligodeoxynucleotides used in ex vivo studies were encapsulated in cationic liposomes $(1 \mu \mathrm{g}$ oligodeoxynucleotide $/ 1 \mu \mathrm{g}$ liposome) prepared using $N$-[1-(2,3-Dioleoyloxy)propyl]- $N, N, N$-trimethylammonium methylsulfate (Boehringer Mannheim, Indianapolis, Indiana, USA). Freshly dissected arterial vessels were placed on culture dishes $(35 \mathrm{~mm})$ containing tissue culture medium (DMEM with 10\% Nu-serum,
$100 \mu \mathrm{g} / \mathrm{ml}$ streptomycin, and $100 \mu \mathrm{g} / \mathrm{ml}$ penicillin) plus either HO-1 AS-ODN, HO-2 AS-ODN, both antisense oligodeoxynucleotides in combination, or corresponding scrambled oligodeoxynucleotides (all at 40 $\mu \mathrm{g} / \mathrm{ml}$ ). After incubation for 18 hours at $37^{\circ} \mathrm{C}$ in an atmosphere of $95 \%$ air and $5 \% \mathrm{CO}_{2}$, concentrationresponse curves to phenylephrine or vasopressin were constructed as detailed above. Contractile responses to agonists in vessels treated with oligodeoxynucleotides were studied before and after addition of exogenous $\mathrm{CO}(0.1 \mu \mathrm{mol} / \mathrm{l}$ and $1.0 \mu \mathrm{mol} / \mathrm{l})$ to the buffer.

Oligodeoxynucleotides used in vivo, HO-2 AS-ODN and HO-2 S-ODN, were encapsulated in liposomes (1:1 molar ratio nucleotide/lipid) prepared using premixed 1,2-bis(oleoyloxy)-3-(trimethylammonio) propane and $\mathrm{L}-\alpha$-dioleoyl phosphatidylethanolamine. The cationic mixture along with the instructions for preparation of the cationic lipid/oligomer complex were supplied by Avanti Polar Lipids Inc. (Alabaster, Alabama, USA). Liposomes containing HO-2 AS-ODN or HO-2 S-ODN were suspended in $5 \%$ dextrose and injected $(2 \mathrm{mg} / \mathrm{kg})$ to rats via a cannula placed in a femoral vein. Concentration-response curves to phenylephrine were constructed, as detailed above, in renal interlobar arteries obtained from rats injected 1 day earlier with $\mathrm{HO}-2$ AS-ODN or HO-2 S-ODN.

Protocol 2 investigates the effect of an inhibitor of both HO-1 and HO-2 on vascular responsiveness to constrictor agonists. Concentration-response curves to phenylephrine, vasopressin and $\mathrm{KCl}$ were constructed in freshly isolated vessels bathed in buffer containing and not containing the $\mathrm{HO}$ inhibitor chromium mesoporphyrin (CrMP, $30 \mu \mathrm{mol} / 1$; Porphyrin Products, Logan, Utah, USA). Contractile responses to phenylephrine in CrMP-treated preparations were examined before and after addition of exogenous $\mathrm{CO}(10 \mu \mathrm{mol} / \mathrm{l})$ or biliverdin $(10 \mu \mathrm{mol} / \mathrm{l})$ to the bathing buffer.

Protocol 3 examines the vascular responsiveness to phenylephrine before and 15 minutes after inclusion into the bathing buffer of a potassium channel blocker, tetraethylammonium (TEA; $1 \mathrm{mmol} / \mathrm{l}$ ) or iberiotoxin $(10 \mathrm{nmol} / \mathrm{l})$. The responsiveness to phenylephrine also was examined in vessels treated concurrently with TEA plus CrMP $(30 \mu \mathrm{mol} / \mathrm{l})$, with TEA plus HO-1 AS-ODN $(40 \mu \mathrm{g} / \mathrm{ml})$ and HO-2 AS-ODN $(40 \mu \mathrm{g} / \mathrm{ml})$, with TEA plus HO-1 AS-ODN, HO-2 AS-ODN, and exogenous $\mathrm{CO}(10 \mu \mathrm{mol} / \mathrm{l})$.

Patch-clamp studies. The effect of the HO inhibitor CrMP $(30 \mu \mathrm{mol} / \mathrm{l})$ and of $\mathrm{CO}(10 \mu \mathrm{mol} / \mathrm{l})$ on $\mathrm{K}^{+}$channel currents was studied in smooth muscle cells isolated from rat renal interlobar arteries according to a published procedure (17). The effect of $\mathrm{CO}$ was investigated in cells bathed in media with and without $1 \mathrm{H}-[1,2,4]$ oxadiazolo[4,3- $\alpha$ ] quinoxalin-1-one (ODQ; 10 $\mu \mathrm{mol} / \mathrm{l})$, an inhibitor of soluble guanylyl cyclase. $\mathrm{K}^{+}$ channel currents also were examined in smooth muscle cells obtained from rat renal interlobar arteries maintained for 18 hours prior to experimentation in tissue 
culture medium containing HO-2 AS-ODN or HO-2 S-ODN ( $40 \mu \mathrm{g} / \mathrm{ml}$ for both ODNs). Experiments were conducted within 4 hours of completing isolation of the vascular smooth muscle cells, utilizing the patch-clamp technique as reported previously $(17,18)$. $\mathrm{K}^{+}$currents were recorded using the cell-attached configuration; in some experiments, recordings also were made in insideout membrane patches. The pipette solution contained (in mmol/l) $140 \mathrm{KCl}, 1.8 \mathrm{MgCl}_{2}$, and $10 \operatorname{HEPES}(\mathrm{pH}$ 7.4). The composition of the bath solution used in experiments with cell-attached patches was (in $\mathrm{mmol} / \mathrm{l}$ ) $140 \mathrm{NaCl}, 5 \mathrm{KCl}, 1.8 \mathrm{MgCl}_{2}, 1.8 \mathrm{CaCl}_{2}$, and 10 HEPES ( $\mathrm{pH}$ 7.4). The composition of the bath solution used in experiments with inside-out patches was as above except the concentration of $\mathrm{CaCl}_{2}$ was varied between 0 and 1 $\mu \mathrm{mol} / \mathrm{l})$. When so noted, 8 -Bromo-cGMP $(0.1 \mathrm{mmol} / \mathrm{l})$ was included in the bath solution in order to boost the activity of K channels, which under resting conditions is low (17). The open state probability $\left(\mathrm{NP}_{0}\right)$ was calculated from data sampled over a 30-60 second interval in the steady state, during control and experimental periods. The following equation was used to calculate $\mathrm{NP}_{0}: \mathrm{NP}_{0}=\Sigma\left(\mathrm{t}_{1}+\mathrm{t}_{2}+\ldots+\mathrm{t}_{\mathrm{i}}\right)$, where $\mathrm{t}_{\mathrm{i}}$ is the fractional open time spent at each of the observed current levels. A $105 \pm 5$ pS K channel was identified in both cellattached and inside-out patches. The activity of this channel was inhibited by TEA $(100 \mu \mathrm{mol} / \mathrm{l})$ and by exposure to a bath solution lacking in $\mathrm{Ca}^{++}$.

Analysis of $\mathrm{HO}$ proteins and $\mathrm{CO}$ release. $\mathrm{HO}-1$ and $\mathrm{HO}-2$ protein expression was assessed in pools of freshly isolated interlobar arteries (arteries from six rats in each pool) and in pools of vessels incubated for 18 hours as detailed above in tissue culture medium containing either HO-2 AS-ODN or HO-2 S-ODN (both at 40 $\mu \mathrm{g} / \mathrm{ml})$. The vessels were homogenized, the homogenate was centrifuged, and the $10,000 \mathrm{~g}$ supernatant was analyzed for HO-1 and HO-2 by immunoblotting as previously described (10). HO activity was measured in the 10,000 g supernatant $(8)$ using $\left[{ }^{14} \mathrm{C}\right]$ heme (Leeds Radioporphyrins, Leeds, United Kingdom) as substrate; HO activity is expressed as picomoles of bilirubin generated per milligram of protein per hour.

Interlobar artery specimens maintained for 18 hours in culture media containing HO-2 AS-ODN or HO-2 $\mathrm{S}$-ODN were compared in terms of ability to release $\mathrm{CO}$. Vessels so treated were transferred into amber glass vials $(2 \mathrm{ml})$ containing $1.0 \mathrm{ml}$ of Krebs' buffer saturated with $95 \% \mathrm{O}_{2}$ and $5 \% \mathrm{CO}_{2}$, the vials were capped tightly with rubberized Teflon liners, and the samples were incubated at $37^{\circ} \mathrm{C}$ for 60 minutes. The incubations were terminated by placement of the samples in ice. Subsequently, internal standards made of isotopically labeled $\mathrm{CO}\left({ }^{13} \mathrm{C}^{16} \mathrm{O}\right.$ and $\left.{ }^{13} \mathrm{C}^{18} \mathrm{O}\right)$ were injected into samples, and the $\mathrm{CO}$ content of the headspace gas was determined by gas chromatography/mass spectroscopy analysis. Release of $\mathrm{CO}$ also was examined during incubation (1 hour) in Krebs' buffer of freshly isolated interlobar arteries obtained from untreated rats and rats treated 1 day earlier with HO-2 AS-ODN or HO-2 S-ODN, as described above. In selected experiments, $\mathrm{CO}$ release was measured in vessels incubated in buffer containing CrMP $(30 \mu \mathrm{mol} / \mathrm{l})$.

The analyses of CO were performed using a HP5989A mass spectrometer interfaced to a HP 5890 gas chromatograph. The separation of $\mathrm{CO}$ from other gases was carried out on a GS-Molesieve capillary column $(30 \mathrm{~m}$ length; $0.53 \mathrm{~mm}$ internal diameter; J \& W Scientific Inc., Folsom, California, USA) kept at $40^{\circ} \mathrm{C}$. Helium was used as the carrier gas with a linear velocity of $0.3 \mathrm{~m} / \mathrm{s}$. $\mathrm{CO}$ eluted at 3.6 minutes and was fully separated from $\mathrm{N}_{2}, \mathrm{O}_{2}, \mathrm{H}_{2} \mathrm{O}$, and $\mathrm{CO}_{2}$. The mass spectrometer parameters were as follows: ion source temperature, $120^{\circ} \mathrm{C}$; electron energy, $31 \mathrm{eV}$; and transfer line temperature, $120^{\circ} \mathrm{C}$. Aliquots $(100 \mu \mathrm{l})$ of the headspace gas of either standard solutions or experimental samples were injected using a gas-tight syringe into the splitless injector having a temperature of $120^{\circ} \mathrm{C}$. Abundance of ions at $m / z 28,29$, and 31 corresponding to ${ }^{12} \mathrm{C}^{16} \mathrm{O},{ }^{13} \mathrm{C}^{16} \mathrm{O}$, and ${ }^{13} \mathrm{C}^{18} \mathrm{O}$, respectively, was acquired via a selected ion monitoring. The amount of $\mathrm{CO}$ in samples was calculated from standard curves constructed with abundance of ions $\mathrm{m} / \mathrm{z} 28$ and $\mathrm{m} / \mathrm{z} 29$ or $\mathrm{m} / \mathrm{z} 31$. Both standard curves were linear over the range $0.05-5.0 \mu \mathrm{mol} / \mathrm{l}$ and both yielded comparable results when used for determining the concentration of endogenous $\mathrm{CO}$. The sensitivity of the assay is $5 \mathrm{pmol}$ of $\mathrm{CO}$. The results were expressed as pmol of $\mathrm{CO}$ released into the headspace gas per milligram of protein per hour. The protein content of vascular specimens was measured using the Bio-Rad microassay (Bio-Rad Laboratories Inc., Hercules, California, USA) with bovine serum albumin as standard.

Data analysis. Data are expressed as mean \pm SEM. Concentration-response data derived from each vessel were fitted separately to a logistic function by nonlinear regression and the maximum asymptote of the curve $\left(\mathrm{R}_{\max }\right)$ and concentration of agonist producing $50 \%$ of the maximal response $\left(\mathrm{EC}_{50}\right)$ were calculated using commercially available software (Prism 2.01; GraphPAD Software for Science Inc., San Diego, California, USA). Concentration-response data were analyzed by a two-way ANOVA followed by a Duncan multiple range test. All other data were analyzed by a one-way analysis of variance or the Student's $t$ test for paired or unpaired samples as appropriate. The null hypothesis was rejected at $P<0.05$.

\section{Results}

$\mathrm{HO}$ expression and CO production in renal arterial vessels. A protein with the molecular mass of $\mathrm{HO}-2$ was identified by immunoblotting in homogenates of freshly isolated renal interlobar arteries and in interlobar arteries maintained in organ culture for 18 hours (Figure 1); HO-2 expression in vessels maintained in media containing HO- 2 AS-ODN (33,706 \pm 7,061 arbitrary densitometry units, $n=6)$ was reduced $(P<0.05)$ relative to that in vessels maintained in media containing HO-2 S-ODN $(61,200 \pm 8,599$ arbitrary densitometry units, $n=6$ ). HO-1 was not apparent in either freshly 


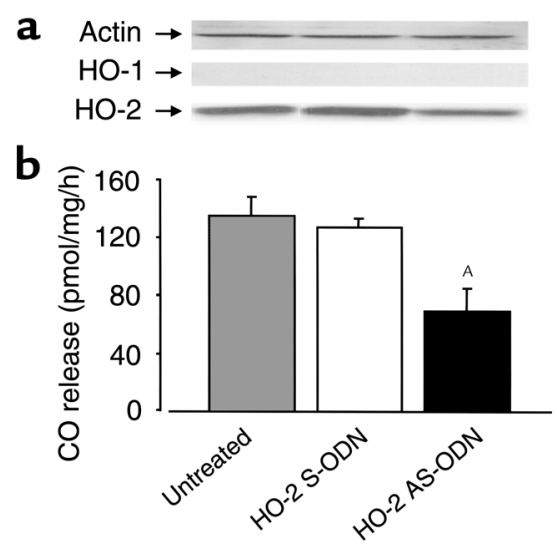

Figure 1

Assessment of $\mathrm{HO}-1$ and $\mathrm{HO}-2$ expression by immunoblotting (a) and of CO release into the headspace (b) in freshly isolated rat renal interlobar arteries and in arterial specimens maintained in organ culture for 18 hours prior to testing in media containing HO-2 AS-ODN (40 $\mu \mathrm{g} / \mathrm{ml}$ ) or the corresponding scrambled oligodeoxynucleotides ( $\mathrm{HO}-2$ S-ODN, $40 \mu \mathrm{g} / \mathrm{ml}$ ). Results in a are representative of six experiments and in $\mathbf{b}$ are the mean \pm SEM of four experiments. In $\mathbf{a}$, the expression of $\beta$-actin is taken as an index of the adequacy of sample loading. AP $<0.05$ relative to data in vessels treated with HO-2 S-ODN.

isolated vessels or vessels maintained in media containing HO-2 AS-ODN or HO-2 S-ODN (Figure 1). $\mathrm{HO}$ activity in renal interlobar arteries kept for 18 hours in culture media containing HO-2 AS-ODN $(196 \pm 16 \mathrm{pmol} / \mathrm{mg} / \mathrm{h} ; n=4)$ was diminished $(P<0.05)$ relative to $\mathrm{HO}$ activity values in vessels kept in media containing HO-2 S-ODN $(331 \pm 29 \mathrm{pmol} / \mathrm{mg} / \mathrm{h} ; n=4)$ or in untreated freshly isolated vessels $(338 \pm 41$ $\mathrm{pmol} / \mathrm{mg} / \mathrm{h} ; n=4)$. Renal interlobar arteries released $\mathrm{CO}$ into the headspace during incubation in Krebs' buffer (Figure 1); CO release from vessels treated ex vivo with HO-2 AS-ODN was surpassed $(P<0.05)$ by both the release from vessels treated with $\mathrm{HO}-2$ $\mathrm{S}-\mathrm{ODN}$ and from untreated fresh vessels. Renal interlobar arteries obtained from rats injected with $\mathrm{HO}-2$ AS-ODN 1 day earlier released less CO (52.8 \pm 12.4 $\mathrm{pmol} / \mathrm{mg} / \mathrm{h} ; n=4 ; P<0.05)$ than vessels obtained from rats treated with HO-2 S-ODN (130.2 \pm 23.1 $\mathrm{pmol} / \mathrm{mg} / \mathrm{h} ; n=4)$. CO release from freshly isolated renal interlobar arteries incubated for 1 hour in buffer containing the HO inhibitor CrMP $(29.0 \pm 5.1$ $\mathrm{pmol} / \mathrm{mg} / \mathrm{h} ; n=6)$ was surpassed $(P<0.05)$ by the release from control vessels incubated in buffer without CrMP $(94.7 \pm 15.8 \mathrm{pmol} / \mathrm{mg} / \mathrm{h} ; n=6)$. Freshly isolated vessels released comparable amounts of $\mathrm{CO}$ when incubated in buffer containing (174.4 \pm 27.1 $\mathrm{pmol} / \mathrm{mg} / \mathrm{h} ; n=5)$ and not containing $(158.9 \pm 15.9$ $\mathrm{pmol} / \mathrm{mg} / \mathrm{h} ; n=5)$ phenylephrine $(1 \mu \mathrm{mol} / \mathrm{l})$.

Effect of interventions that decrease $\mathrm{CO}$ production on vascular reactivity to constrictor agonists. Figure 2 contrasts renal interlobar artery ring preparations treated ex vivo with HO antisense oligodeoxynucleotides or corresponding scrambled oligodeoxynucleotides in terms of contractile responsiveness to phenylephrine. Maximal responses to the agonist were about the same in all treatment groups. The concentration-response curve to phenylephrine in vessels treated with HO-1 AS-ODN was not distinguishable from that in vessels treated with HO-1 S-ODN. In contrast, relative to the data in preparations treated with HO-2 S-ODN, in vessels treated with HO-2 AS-ODN it was shifted to the left
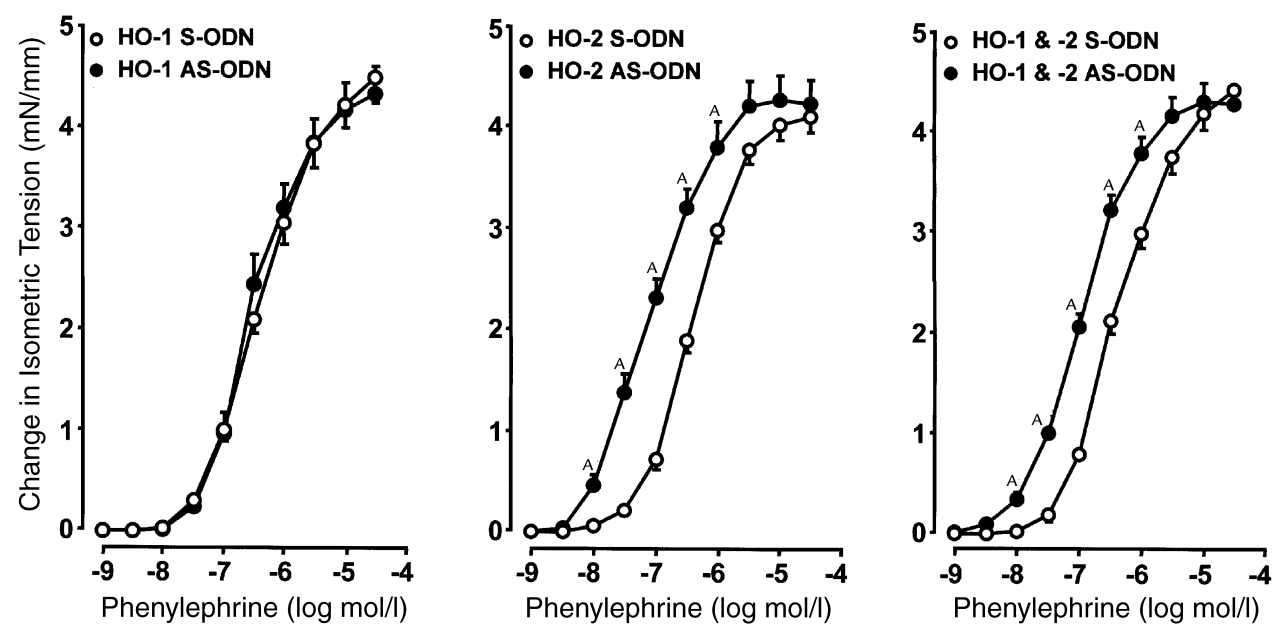

Figure 2

Concentration-response curves to phenylephrine in rat renal interlobar artery rings maintained in organ culture for 18 hours prior to testing in media containing HO-1 AS-ODN $\left(40 \mu \mathrm{g} / \mathrm{ml} ; \mathrm{EC}_{50}, 0.45 \pm 0.15 \mu \mathrm{mol} / \mathrm{l} ; \mathrm{R}_{\max }, 4.33 \pm 0.28 \mathrm{mN} / \mathrm{mm} ; n=8\right)$ or the corresponding scrambled oligodeoxynucleotide (HO-1 S-ODN, $\left.40 \mu \mathrm{g} / \mathrm{ml} ; \mathrm{EC}_{50}, 0.52 \pm 0.05 \mu \mathrm{mol} / \mathrm{l} ; \mathrm{R}_{\max }, 4.41 \pm 0.24 \mathrm{mN} / \mathrm{mm} ; n=8\right)($ left panel), HO-2 AS-ODN $\left(40 \mu \mathrm{g} / \mathrm{ml} ; \mathrm{EC}_{50}, 0.13 \pm 0.02^{\mathrm{A}} \mu \mathrm{mol} / \mathrm{l} ; \mathrm{R}_{\max }, 4.26 \pm 0.25 \mathrm{mN} / \mathrm{mm} ; n=16\right)$ or the corresponding scrambled oligodeoxynucleotides (HO-2 S-ODN, $40 \mu \mathrm{g} / \mathrm{ml}$; EC $50,0.46 \pm 0.04 \mu \mathrm{mol} / \mathrm{l} ; \mathrm{R}_{\max }, 4.18 \pm 0.17 \mathrm{mN} / \mathrm{mm} ; n=17$ ) (middle panel), both HO-1 AS-ODN and HO-2 AS-ODN (EC $\left.50,0.14 \pm 0.02^{\mathrm{A}} \mu \mathrm{mol} / \mathrm{l} ; \mathrm{R}_{\max }, 4.28 \pm 0.20 \mathrm{mN} / \mathrm{mm} ; n=17\right)$ or HO-1 S-ODN and HO-2 S-ODN in combination (EC 50 , $\left.0.52 \pm 0.06 \mu \mathrm{mol} / \mathrm{l} ; \mathrm{R}_{\max }, 4.46 \pm 0.16 \mathrm{mN} / \mathrm{mm} ; n=8\right)$ (right panel). L-NAME $(1 \mathrm{mmol} / \mathrm{l})$ was included in the buffer used in contractility studies. Results are mean \pm SEM. ${ }^{A} P<0.05$ relative to corresponding data in vessels treated with scrambled oligodeoxynucleotides. 
a

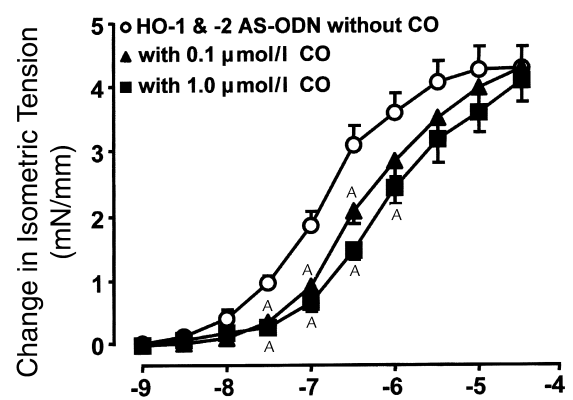

b

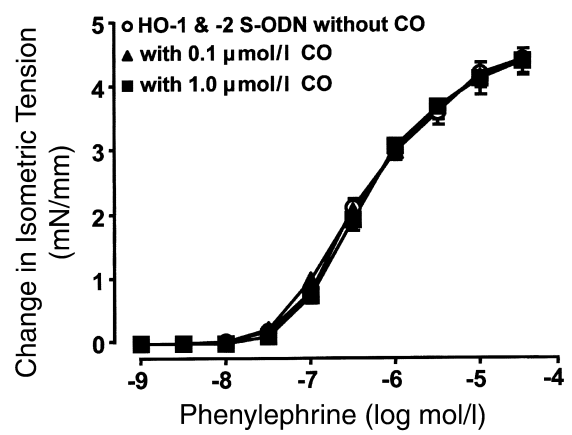

Figure 3

Effect of exogenous $\mathrm{CO}$ on phenylephrine-induced contraction of rat renal interlobar artery rings maintained in organ culture for 18 hours prior to experimentation in media containing both HO-1 AS-ODN (40 $\mu \mathrm{g} / \mathrm{ml})$ and HO-2 AS-ODN $(40 \mu \mathrm{g} / \mathrm{ml})(\mathbf{a})$ or the corresponding scrambled oligodeoxynucleotides (HO-1 S-ODN and HO-2 S-ODN, both at $40 \mu \mathrm{g} / \mathrm{ml}$ ) (b). (a) HO-1 AS-ODN + HO-2 AS-ODN without CO $\left(\mathrm{EC}_{50}\right.$, $\left.0.16 \pm 0.02 \mu \mathrm{mol} / \mathrm{l} ; \mathrm{R}_{\max }, 4.24 \pm 0.37 \mathrm{mN} / \mathrm{mm} ; n=9\right)$, with $0.1 \mu \mathrm{mol} / \mathrm{I}$ $\mathrm{CO}\left(\mathrm{EC}_{50}, 0.53 \pm 0.06^{\mathrm{A}} \mu \mathrm{mol} / \mathrm{l} ; R_{\max }, 4.14 \pm 0.29 \mathrm{mN} / \mathrm{mm} ; n=9\right)$. and with $1.0 \mu \mathrm{mol} / \mathrm{I} \mathrm{CO}\left(\mathrm{EC}_{50}, 0.84 \pm 0.10^{\mathrm{A}} \mu \mathrm{mol} / \mathrm{l} ; \mathrm{R}_{\max }, 4.08 \pm 0.33\right.$ $\mathrm{mN} / \mathrm{mm} ; n=9)$. (b) HO-1 S-ODN + HO-2 S-ODN without CO $\left(\mathrm{EC}_{50}\right.$, $\left.0.52 \pm 0.06 \mu \mathrm{mol} / \mathrm{l} ; R_{\max }, 4.31 \pm 0.16 \mathrm{mN} / \mathrm{mm} ; n=8\right)$, with $0.1 \mu \mathrm{mol} / \mathrm{l}$ $\mathrm{CO}\left(\mathrm{EC}_{50}, 0.49 \pm 0.07 \mu \mathrm{mol} / \mathrm{l} ; \mathrm{R}_{\max }, 4.27 \pm 0.19 \mathrm{mN} / \mathrm{mm} ; n=8\right)$, and with $1.0 \mu \mathrm{mol} / \mathrm{I} \mathrm{CO}\left(\mathrm{EC}_{50}, 0.47 \pm 0.06 \mu \mathrm{mol} / \mathrm{l} ; \mathrm{R}_{\max }, 4.29 \pm 0.18\right.$ $\mathrm{mN} / \mathrm{mm} ; n=8)$. L-NAME $(1 \mathrm{mmol} / \mathrm{I})$ was included in the buffer used in contractility studies. Results are mean \pm SEM. ${ }^{A} P<0.05$ relative to corresponding data in vessels not exposed to exogenous $C O$.

and the $\mathrm{EC}_{50}$ was decreased $(P<0.05)$, which indicates sensitization to the agonist. A similar increase in sensitivity to phenylephrine was found in preparations treated with both HO-2 AS-ODN and HO-1 AS-ODN. The concentration-response curve to phenylephrine in vessels maintained for 18 hours in media without added oligodeoxynucleotides $\left(\mathrm{EC}_{50}, 0.42 \pm 0.05 \mu \mathrm{mol} / \mathrm{l}\right.$, $\mathrm{R}_{\max }, 4.28 \pm 0.25 \mathrm{mN} / \mathrm{mm} ; n=9$ ) was nearly superimposable with the concentration-response curves obtained in vessels maintained for 18 hours in media containing HO-1 S-ODN, HO-2 S-ODN, or HO-1 $\mathrm{S}-\mathrm{ODN}$ and HO-2 S-ODN in combination.

Sensitization to the constrictor action of phenylephrine after ex vivo treatment with HO-2 AS-ODN and HO-1 AS-ODN combined also was demonstrable in renal interlobar arteries bathed in media without L-NAME. The $\mathrm{EC}_{50}$ for phenylephrine in such vessels $(n=9)(0.22 \pm 0.05$ $\mu \mathrm{mol} / \mathrm{l})$ was smaller $(P<0.05)$ than in vessels treated with
HO-2 S-ODN and HO-1 S-ODN combined $(n=6)$ $(0.49 \pm 0.07 \mu \mathrm{mol} / \mathrm{l})$, whereas the $\mathrm{R}_{\max }$ value was comparable ( $4.32 \pm 0.36$ versus $4.08 \pm 0.24 \mathrm{mN} / \mathrm{mm}$ ).

The constrictor responsiveness to phenylephrine also was studied in renal interlobar arteries freshly isolated from rats injected 1 day before experimentation with HO-2 AS-ODN or HO-2 S-ODN. The phenylephrine concentration-response curve in vessels from rats treated with HO-2 AS-ODN $(n=8)$ was shifted to the left of that obtained in vessels from rats treated with HO-2 S-ODN $(n=8)$; the $\mathrm{EC}_{50}$ was decreased $(P<0.05)(0.15 \pm 0.02$ versus $0.32 \pm 0.03$ $\mu \mathrm{mol} / \mathrm{l})$, whereas, the $\mathrm{R}_{\max }$ was not altered $(3.96 \pm 0.19$ versus $4.16 \pm 0.13 \mathrm{mN} / \mathrm{mm}$ ).

As shown in Figure 3, the sensitization caused by ex vivo treatment with both HO-1 AS-ODN and HO-2 AS-ODN was completely offset by exogenous CO, which caused a rightward displacement of the concen-

\section{a}

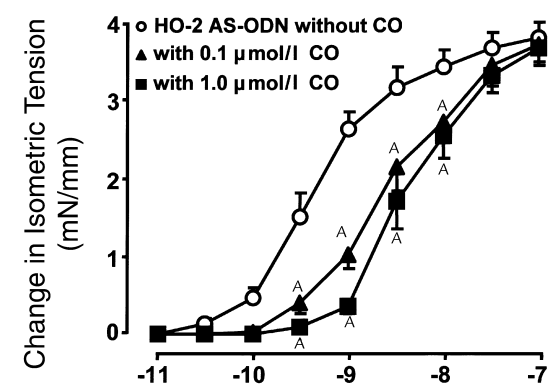

b

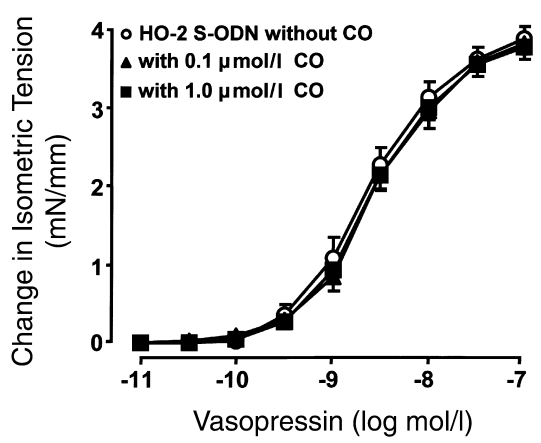

\section{Figure 4}

Concentration-response curve to vasopressin in rat renal interlobar artery rings maintained in organ culture for 18 hours prior to experimentation in media containing HO-2 AS-ODN $(40 \mu \mathrm{g} / \mathrm{ml})(\mathbf{a})$ or the corresponding scrambled oligodeoxynucleotides (HO-2 S-ODN, $40 \mu \mathrm{g} / \mathrm{ml}$ ) (b). (a) HO-2 AS-ODN without CO (EC $50,0.71 \pm 0.15$ $\left.\mathrm{nmol} / \mathrm{l} ; \mathrm{R}_{\max }, 3.74 \pm 0.22 \mathrm{mN} / \mathrm{mm} ; n=9\right)$, with $0.1 \mu \mathrm{mol} / \mathrm{I} \mathrm{CO}$ $\left(E C_{50}, 5.59 \pm 2.07^{A} \mathrm{nmol} / \mathrm{l} ; R_{\max }, 3.81 \pm 0.23 \mathrm{mN} / \mathrm{mm} ; n=9\right)$, and with $1.0 \mu \mathrm{mol} / \mathrm{I} \mathrm{CO}\left(\mathrm{EC}_{50}, 8.20 \pm 2.71^{\mathrm{A}} \mathrm{nmol} / \mathrm{l} ; \mathrm{R}_{\max }, 4.04 \pm 0.30\right.$ $\mathrm{mN} / \mathrm{mm} ; n=9)$. (b) HO-2 S-ODN without $\mathrm{CO}\left(\mathrm{EC}_{50}, 3.67 \pm 0.70\right.$ $\left.\mathrm{nmol} / \mathrm{l} ; \mathrm{R}_{\max }, 3.97 \pm 0.13 \mathrm{mN} / \mathrm{mm} ; n=9\right)$, with $0.1 \mu \mathrm{mol} / \mathrm{l} \mathrm{CO}$ $\left(E C_{50}, 4.62 \pm 1.06 \mathrm{nmol} / \mathrm{l} ; R_{\max }, 3.96 \pm 0.11 \mathrm{mN} / \mathrm{mm} ; n=9\right)$, and with $1.0 \mu \mathrm{mol} / \mathrm{I} C O\left(E C_{50}, 3.75 \pm 0.50 \mathrm{nmol} / \mathrm{l} ; R_{\max }, 3.88 \pm 0.15\right.$ $\mathrm{mN} / \mathrm{mm} ; n=9)$. The experiments were conducted with and without addition of exogenous $\mathrm{CO}$ to the bathing buffer. L-NAME $(1 \mathrm{mmol} / \mathrm{l})$ was included in the buffer used in contractility studies. Results are the mean \pm SEM. ${ }^{A} P<0.05$ relative to corresponding data in vessels not exposed to exogenous $\mathrm{CO}$. 

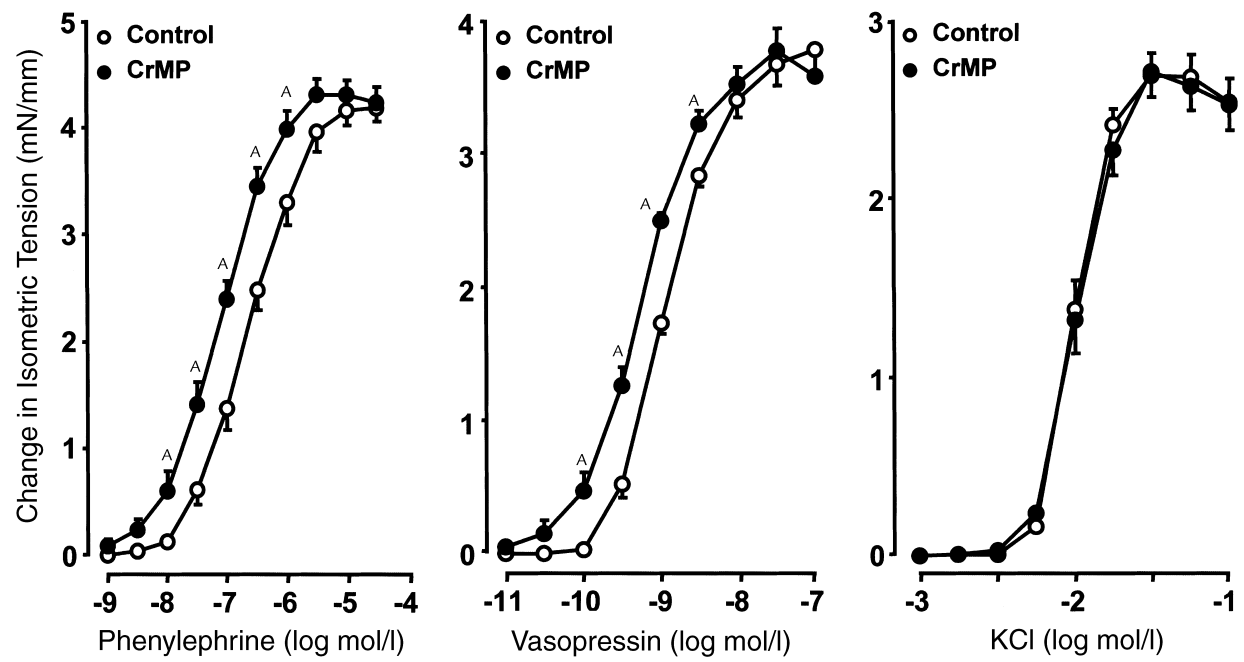

Figure 5

Concentration-response curves to phenylephrine (left panel), vasopressin (middle panel) and $\mathrm{KCl}$ (right panel) in freshly dissected rat renal interlobar artery rings bathed in buffer containing and not containing $\mathrm{CrMP}(30 \mu \mathrm{mol} / \mathrm{l})$. Left panel: control $\left(E C_{50}, 0.33 \pm 0.05 \mu \mathrm{mol} / \mathrm{l} ; \mathrm{R}_{\max }\right.$, $4.22 \pm 0.14 \mathrm{mN} / \mathrm{mm} ; n=13), \operatorname{CrMP}\left(\mathrm{EC}_{50}, 0.11 \pm 0.02^{\mathrm{A}} \mu \mathrm{mol} / \mathrm{l} ; \mathrm{R}_{\max }, 4.32 \pm 0.12 \mathrm{mN} / \mathrm{mm} ; n=13\right)$; middle panel: control $\left(\mathrm{EC}_{50}, 1.55 \pm 0.09\right.$ $\left.\mathrm{nmol} / \mathrm{l} ; \mathrm{R}_{\max }, 3.84 \pm 0.21 \mathrm{mN} / \mathrm{mm} ; n=7\right), \mathrm{CrMP}\left(\mathrm{EC}_{50}, 0.70 \pm 0.11^{\mathrm{A}} \mathrm{nmol} / \mathrm{l} ; \mathrm{R}_{\max }, 3.77 \pm 0.17 \mathrm{mN} / \mathrm{mm} ; n=7\right)$; right panel: control (EC 50 , $\left.15.19 \pm 1.26 \mathrm{mmol} / \mathrm{l} ; \mathrm{R}_{\max }, 2.91 \pm 0.13 \mathrm{mN} / \mathrm{mm} ; n=8\right), \mathrm{CrMP}\left(\mathrm{EC}_{50}, 16.33 \pm 2.28 \mathrm{mmol} / \mathrm{l} ; \mathrm{R}_{\max }, 2.93 \pm 0.15 \mathrm{mN} / \mathrm{mm} ; n=8\right) . \mathrm{L}-\mathrm{NAME}$ $(1 \mathrm{mmol} / \mathrm{l})$ was included in the buffer used in contractility studies. Results are means $\pm \mathrm{SEM}$. ${ }^{A} P<0.05$ relative to corresponding data in vessels not exposed to CrMP.

tration-response curve to phenylephrine and increased the $\mathrm{EC}_{50}(P<0.05)$ without altering the maximal response. Notably, exogenous $\mathrm{CO}$ did not affect any aspect of the phenylephrine concentration-response curve in control vessels treated with HO-1 S-ODN and HO-2 S-ODN in combination.

Figure 4 illustrates the concentration-response relationship for vasopressin in renal interlobar artery rings treated with HO-2 S-ODN or HO-2 AS-ODN, with and without addition of $\mathrm{CO}$ to the bathing buffer. The maximal response to vasopressin was the same in vessels treated with HO-2 S-ODN or HO-2 AS-ODN. However, the concentration-response curve to vasopressin was displaced to the left, and the $\mathrm{EC}_{50}$ was decreased (from $3.67 \pm 0.70$ to $0.71 \pm 0.15 \mathrm{nmol} / 1, P<0.05$ ), in vessels treated with HO-2 AS-ODN compared with data in preparations treated with $\mathrm{HO}-2 \mathrm{~S}-\mathrm{ODN}$. The increased sensitivity to vasopressin after HO-2 AS-ODN treatment was offset by exogenous $\mathrm{CO}$. Yet exogenous $\mathrm{CO}$ did not affect any aspect of vasopressin concentrationresponse curve in vessels treated with HO-2 S-ODN.

\section{Figure 6}

A channel recording showing the effects of $\operatorname{CrMP}(30 \mu \mathrm{mol} / \mathrm{l})$ alone and with exogenous $\mathrm{CO}(10 \mu \mathrm{mol} / \mathrm{l})$ on the activity of $\mathrm{Ca}^{++}$-activated $\mathrm{K}$ channels in a smooth muscle cell isolated from the rat renal interlobar artery. The experiment was performed in a cell-attached patch bathed in media containing $0.1 \mathrm{mmol} / \mathrm{l}$ 8-bromo-cGMP. The holding potential was $0 \mathrm{mV}$. The channel closed level is indicated by C. The top recording shows the time-course of the experiment; the segments of the recording indicated by the numbers $1-3$ are presented below at fast time resolution.
Figure 5 depicts the concentration-response relationships for phenylephrine, vasopressin, and $\mathrm{KCl}$ in renal interlobar artery rings treated and not treated with the $\mathrm{HO}$ inhibitor CrMP. The concentration-response curve to $\mathrm{KCl}$ was unaffected by CrMP. CrMP did not affect the maximal response to either phenylephrine or vasopressin. However, for both agonists, treatment with CrMP caused a leftward shift in the concentrationresponse curve and a decrease in $\mathrm{EC}_{50}$ values $(P<0.05)$, which denotes sensitization of vascular smooth muscle to the agonists. In vessels treated with CrMP, CO (10 $\mu \mathrm{mol} / \mathrm{l})$ caused a rightward displacement in the concentration-response curve to phenylephrine and
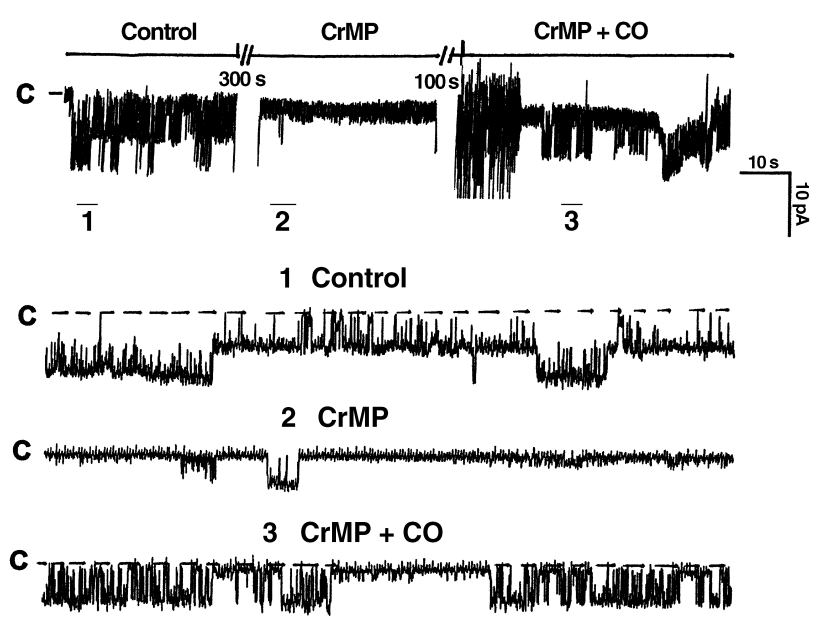

$\stackrel{0.5 \mathrm{~s}}{\frac{0}{\mathrm{D}}}$ 


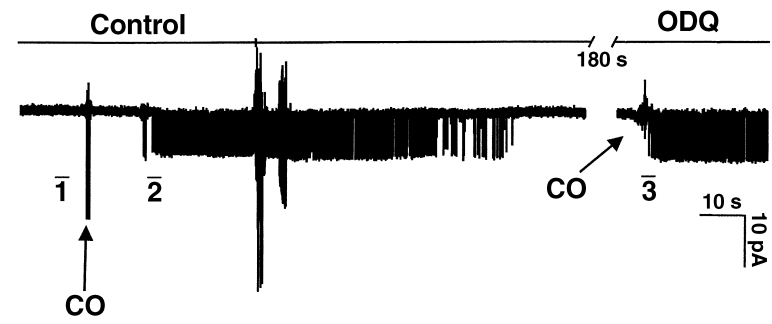

1 Control
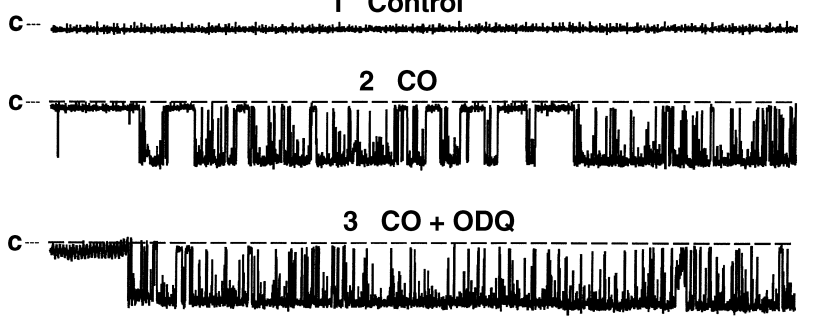

$\stackrel{0.2 \mathrm{~s}}{\square}$

Figure 7

A channel recording showing the effect of exogenous $\mathrm{CO}(10 \mu \mathrm{mol} / \mathrm{I})$ alone and in conjunction with the guanylyl cyclase inhibitor ODQ (10 $\mu \mathrm{mol} / \mathrm{I})$ on the activity of $\mathrm{Ca}^{++}$-activated $\mathrm{K}$ channels in a smooth muscle cell isolated from the rat renal interlobar artery. The experiment was performed in a cell-attached patch bathed in media without 8-bromo-cGMP. The holding potential was $0 \mathrm{mV}$. The channel closed level is indicated by $C$. The top recording shows the time-course of the experiment; the segments of the recording indicated by the numbers 1-3 are presented below at fast time resolution.

increased $(P<0.05)$ the $\mathrm{EC}_{50}(0.11 \pm 0.02$ to $0.24 \pm 0.06$ $\mu \mathrm{mol} / \mathrm{l} ; n=6)$ without affecting the maximal response. In contrast, biliverdin $(10 \mu \mathrm{mol} / \mathrm{l})$ did not affect any aspect of the concentration-response curve to phenylephrine in CrMP-treated vessels $\left(\mathrm{EC}_{50}, 0.13 \pm 0.04\right.$ $\left.\mu \mathrm{mol} / 1 ; \mathrm{R}_{\max }, 4.05 \pm 0.07 \mathrm{mN} / \mathrm{mm} ; n=4\right)$.

CrMP also increased the sensitivity to the constrictor action of phenylephrine in renal interlobar arteries bathed in media without L-NAME and in interlobar arteries denuded of endothelium by rubbing. The HO inhibitor decreased the $\mathrm{EC}_{50}$ for phenylephrine (from $0.35 \pm 0.01$ to $0.08 \pm 0.02 \mu \mathrm{mol} / 1 ; P<0.05, n=4)$ without affecting the $\mathrm{R}_{\max }(4.33 \pm 0.28$ versus $4.25 \pm 0.28$ $\mathrm{mN} / \mathrm{mm}, n=4)$ in vessels not exposed to L-NAME. CrMP also decreased the $\mathrm{EC}_{50}$ for phenylephrine $(0.24 \pm 0.02$ to $0.16 \pm 0.01 \mu \mathrm{mol} / \mathrm{l} ; P<0.05, n=12)$ without affecting the $\mathrm{R}_{\max }(4.05 \pm 0.14$ versus $4.04 \pm 0.13 \mathrm{mN} / \mathrm{mm})$ in endothelium-denuded vessels.

Effect of $H O$ inhibition on $K$ channel currents in vascular smooth muscle: relation to vascular reactivity. A $105 \pm 5 \mathrm{pS}$ $\mathrm{K}$ channel, activated by $\mathrm{Ca}^{++}$and inhibited by TEA, was identified in renal interlobar artery smooth muscle cells bathed in media containing $0.1 \mathrm{mmol} / 1$ 8-bromocGMP. The effect of CrMP on $\mathrm{K}$ channel activity recorded from cell-attached patches is illustrated in Figure 6. CrMP reduced channel activity and decreased $\mathrm{NP}_{0}$ from $0.72 \pm 0.1$ to $0.05 \pm 0.02(n=4 ; P<0.05)$. In the face of continuous exposure of the cells to CrMP, the addition of exogenous $\mathrm{CO}$ to the bath restored $\mathrm{NP}_{0}$ to near control values $(0.64 \pm 0.10 ; P<0.05)$. CrMP did not affect $\mathrm{K}$ channel activity in inside-out membrane patches exposed to media containing $1 \mu \mathrm{mol} / 1 \mathrm{Ca}^{++}$ $\left(\mathrm{NP}_{0}, 0.60 \pm 0.05\right.$ control versus $0.59 \pm 0.05$ with $\left.\mathrm{CrMP}\right)$.

Figure 7 shows that cell-attached patches of renal interlobar artery smooth muscle cells display little or no $\mathrm{K}^{+}$channel activity when bathed in media without 8-bromo-cGMP $\left(\mathrm{NP}_{0}, 0.04 \pm 0.02 ; n=4\right)$. The addition of exogenous $\mathrm{CO}$ to the bath greatly stimulated $\mathrm{K}^{+}$ channel activity $\left(\mathrm{NP}_{0}, 0.68 \pm 0.12 ; P<0.05\right)$. The stimulatory action of $\mathrm{CO}$ on $\mathrm{K}^{+}$channel activity also was demonstrable in cells bathed in media containing ODQ to inhibit guanylyl cyclase $\left(\mathrm{NP}_{0}, 0.70 \pm 0.15\right)$. Under basal conditions, renal interlobar artery cells obtained from vascular segments treated ex vivo (for 18 hours) with HO-2 AS-ODN $(n=5)$ exhibited less $\mathrm{K}^{+}$ channel activity than corresponding cells obtained from vascular segments treated with HO-2 S-ODN $(n=5)\left(\mathrm{NP}_{0}, 0.01 \pm 0.01\right.$ versus $\left.0.06 \pm 0.02 ; P<0.05\right)$.

As shown in Figure 8, treatment of renal interlobar artery rings with TEA or iberiotoxin produced, like treatment with HO-2 AS-ODN or CrMP, a leftward displacement in the concentration-response curve to phenylephrine and a reduction of $\mathrm{EC}_{50}$ values $(P<0.05)$ without altering the maximal response. The sensitization to phenylephrine in TEA-treated vessels was not enhanced further by concurrent treatment with CrMP. In vessels sensitized to phenylephrine by treatment with both HO-1 AS-ODN and HO-2 AS-ODN $\left(\mathrm{EC}_{50}, 0.11 \pm 0.08 \mu \mathrm{mol} / \mathrm{l} ; \mathrm{R}_{\max }\right.$, $4.33 \pm 0.14 \mathrm{mN} / \mathrm{mm}, n=8$ ), only slight sensitivity enhancement was caused by superimposed treatment with TEA $\left(E_{50}, 0.06 \pm 0.01 \mu \mathrm{mol} / 1 ; \mathrm{R}_{\max }, 4.30 \pm 0.11\right.$ $\mathrm{mN} / \mathrm{mm}, n=8)$. In vessels so treated, exogenous $\mathrm{CO}$

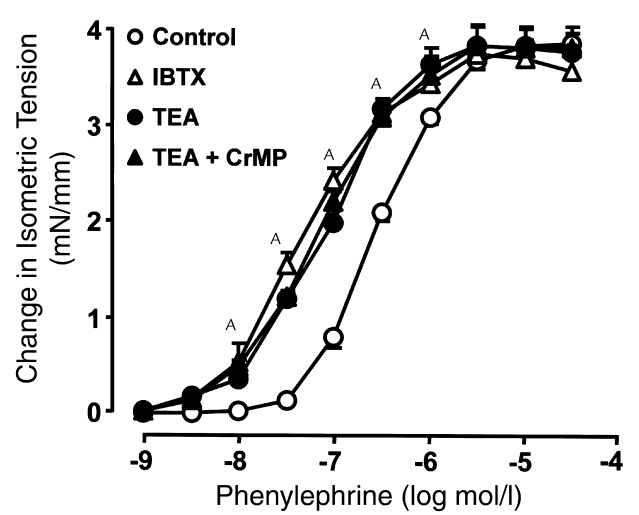

\section{Figure 8}

Concentration-response curves to phenylephrine in freshly dissected rat renal interlobar artery rings bathed in media with $\left(\mathrm{EC}_{50}\right.$, $\left.0.06 \pm 0.01^{\mathrm{A}} \mu \mathrm{mol} / \mathrm{l} ; \mathrm{R}_{\max }, 3.86 \pm 0.18 \mathrm{mN} / \mathrm{mm} ; n=7\right)$ and without iberiotoxin (IBTX, $10 \mathrm{nmol} / \mathrm{l} ; \mathrm{EC}_{50}, 0.38 \pm 0.03 \mu \mathrm{mol} / \mathrm{l} ; \mathrm{R}_{\max }$, $3.96 \pm 0.11 \mathrm{mN} / \mathrm{mm} ; n=15)$, TEA $\left(1 \mathrm{mmol} / \mathrm{l} ; \mathrm{EC}_{50}, 0.10 \pm 0.01^{\mathrm{A}}\right.$ $\left.\mu \mathrm{mol} / \mathrm{l} ; \mathrm{R}_{\max }, 3.87 \pm 0.19 \mathrm{mN} / \mathrm{mm} ; n=8\right)$, or TEA plus CrMP (30 $\mu \mathrm{mol} / \mathrm{l} ; \mathrm{EC}_{50}, 0.09 \pm 0.01^{\mathrm{A}} \mu \mathrm{mol} / \mathrm{l} ; R_{\max }, 3.83 \pm 0.22 \mathrm{mN} / \mathrm{mm}$; $n=8)$. L-NAME ( $1 \mathrm{mmol} / \mathrm{l})$ was included in the buffer used in contractility studies. Results are mean \pm SEM. ${ }^{A} P<0.05$ relative to control. 
$(10 \mu \mathrm{mol} / \mathrm{l})$ did not offset the sensitizing effect of combined inhibition of vascular $\mathrm{HO}$ expression and $\mathrm{K}_{\mathrm{Ca}}$ channel blockade $\left(\mathrm{EC}_{50}, 0.07 \pm 0.01 \mu \mathrm{mol} / \mathrm{l}\right.$; $4.26 \pm 0.11 \mathrm{mN} / \mathrm{mm} ; n=8)$.

\section{Discussion}

This study provides information on the generation of $\mathrm{CO}$ by rat renal interlobar arteries, the influence of endogenous $\mathrm{CO}$ on vascular reactivity to constrictor stimuli, and the involvement of $\mathrm{K}$ channels in the modulatory action of $\mathrm{CO}$ on vascular reactivity. We found that renal arterial vessels manufacture CO which, in turn, reduces the sensitivity of vascular smooth muscle to constrictor agonists via a mechanism involving stimulation of $\mathrm{K}_{\mathrm{Ca}}$ channels. Three key findings substantiate this conclusion.

The first key finding is that segments of rat renal interlobar arteries incubated in Krebs' buffer release $\mathrm{CO}$. CO production in tissues involves both HOdependent and -independent pathways $(1,19)$. In our study, $\mathrm{CO}$ release from arterial vessels was largely HO-dependent since it was decreased to about onethird of the control value by CrMP, which inhibits both HO-1 and HO-2 (20). That vessels treated with HO-2 AS-ODN released less CO than vessels treated with HO-2 S-ODN suggests that heme metabolism by HO-2 is a determinant of basal CO production in arterial vessels. This is in keeping with observations that rat renal interlobar arteries express HO-2 but not HO- 1 and that the vascular expression of HO-2 is reduced by treatment with HO-2 AS-ODN. Yet, under special circumstances, heme metabolism by $\mathrm{HO}-1$ also may contribute to generation of $\mathrm{CO}$ in arterial vessels. For example, the formation of $\mathrm{CO}$ is increased in the aorta of rats subjected to conditions that induce HO-1 expression (9).

The second key finding of our study is that treatment of renal interlobar arteries with HO-2 AS-ODN or CrMP causes a leftward shift in the concentration-response curve to phenylephrine and vasopressin, reducing the $\mathrm{EC}_{50}$ of the agonists but not the maximal response. These results suggest that reduction of HO-2 expression or activity increases the sensitivity of vascular smooth muscle to constrictor agonists. The sensitizing effect may be the manifestation of diminished vascular production of an HO-2 product that decreases the sensitivity of vascular smooth muscle to phenylephrine and vasopressin.

In our study, biliverdin did not reduce the sensitivity of CrMP-treated vessels to phenylephrine. On the other hand, $\mathrm{CO}$ decreased the sensitivity to phenylephrine in vessels treated with CrMP or with both HO-1 AS-ODN and HO-2 AS-ODN, as well as the sensitivity to vasopressin in vessels treated with $\mathrm{HO}-2$ AS-ODN. Hence, $\mathrm{CO}$ is the product of vascular HO activity most likely to serve as an inhibitory modulator of the sensitivity of vascular smooth muscle to the constrictor agonists. Notably, exogenous $\mathrm{CO}$ does not modify the responsiveness to vasoconstrictors in vessels that are not treated with inhibitors of the expres- sion or activity of HO-2. This finding may imply that under such circumstances the vascular reactivity inhibitory mechanism supported by endogenous $\mathrm{CO}$ is maximally active and that no further activation can be achieved with the administration of CO.

The third key finding of our study is that treatment of cGMP-stimulated renal arterial smooth muscle cells with CrMP reduces the open probability of a $105 \mathrm{pS} \mathrm{K}$ channel that requires $\mathrm{Ca}^{++}$for activation and is inhibited by TEA. The open probability of this channel also is diminished in smooth muscle cells obtained from renal interlobar arteries treated ex vivo with HO-2 AS-ODN. That CrMP did not reduce the activity of this channel in inside-out patches argues against direct inhibition of the channel by the $\mathrm{HO}$ inhibitor. Rather, the inhibitory effect of CrMP on K channel activity of cell-attached patches may be attributed to diminished production of HO-derived CO. This is supported by the observation that exogenous $\mathrm{CO}$ increases the open probability of the 105 pS K channel in renal arterial smooth muscle cells pretreated with CrMP, reversing the effect of the $\mathrm{HO}$ inhibitor. Exogenous $\mathrm{CO}$ also stimulates the activity of this channel in renal arterial smooth muscle cells not exposed to cGMP or CrMP. The stimulatory action is cGMP-independent as it is not affected by guanylyl cyclase inhibition with ODQ. Other investigators demonstrated that exogenous $\mathrm{CO}$ stimulates a $238 \mathrm{pS}$ $\mathrm{K}_{\mathrm{Ca}}$ channel in smooth muscle cells of rat tail artery (6), apparently by enhancing the calcium sensitivity of this high conductance channel via a cGMP-independent mechanism (6). Altogether, these observations support the view that $\mathrm{CO}$ arising from heme via metabolism by $\mathrm{HO}$ in vascular smooth muscle subserves a mechanism that brings about stimulation of a $\mathrm{K}$ channel activated by $\mathrm{Ca}^{++}$and inhibited by TEA.

$\mathrm{K}_{\mathrm{Ca}}$ channels in vascular smooth muscle participate in the regulation of membrane potential and hence vascular tone and reactivity (21). Activation of $\mathrm{K}_{\mathrm{Ca}}$ channels hyperpolarizes vascular smooth muscle and elicits vasodilation (21). Conversely, pharmacological blockade of $\mathrm{K}_{\mathrm{Ca}}$ channels depolarizes vascular smooth muscle and causes vasoconstriction in vessels with myogenic tone (22) or undergoing exposure to a constrictor stimulus (17). We found that blockade of $\mathrm{K}_{\mathrm{Ca}}$ channels with TEA or iberiotoxin increased the sensitivity of rat renal interlobar arteries to phenylephrine, mimicking the sensitizing effect of interventions that interfere with the expression or activity of vascular $\mathrm{HO}$.

The sensitizing influence of inhibition of HO synthesis or expression on constrictor responsiveness to agonists, phenylephrine, or vasopressin, may be ascribed to a reduction in the open probability of $\mathrm{K}_{\mathrm{Ca}}$ channels in vascular smooth muscle, consequent to a decrease in $\mathrm{CO}$ production. Two types of observations support this contention. First, the sensitization to phenylephrine in TEA-treated vessels is not enhanced further by concurrent treatment with CrMP, consistent with a common mechanism accounting for the sensitizing action of TEA and the HO inhibitor. Second, in renal arterial ves- 
sels pretreated with both HO-1 AS-ODN and HO-2 AS-ODN, blockade of $\mathrm{K}_{\mathrm{Ca}}$ channels with TEA prevents exogenous $\mathrm{CO}$ from decreasing the sensitivity to phenylephrine. Collectively, these results suggest that $\mathrm{CO}$ of vascular origin attenuates the vascular sensitivity to phenylephrine, and presumably to vasopressin, via a mechanism that involves $\mathrm{K}_{\mathrm{Ca}}$ channels. But endogenous $\mathrm{CO}$ does not appear to attenuate the vascular sensitivity to $\mathrm{KCl}$, since $\mathrm{CrMP}$ did not affect any aspect of the concentration-response curve to $\mathrm{KCl}$ in renal arteries. This is in keeping with evidence that exogenous $\mathrm{CO}$ does not minimize the $\mathrm{KCl}$-induced elevation of cytosolic $\mathrm{Ca}^{++}$in smooth muscle cells (2).

The heme-HO system appears to subserve vasodepressor mechanisms. This is inferred from reports that the administration of HO- 1 inducers lowers blood pressure in hypertensive rats $(23,24)$, whereas in normotensive rats the administration of $\mathrm{HO}$ inhibitors produces systemic vasoconstriction and elevates blood pressure (25). Endogenous CO may contribute to vasodepressor mechanisms by decreasing the activity of central pressor functions (26), reducing the synthesis of endothelin (7), and by minimizing myogenic vascular tone (10). The present study describes a fundamental mechanism by which $\mathrm{CO}$ produced in arterial vessels inhibits vascular reactivity to vasoconstrictors. Accordingly, vascular $\mathrm{CO}$ may serve as a counterregulatory influence to the activity of neurohormonal pressor systems.

\section{Acknowledgments}

This work was supported by NIH grants HL-18579, HL-34300, and DK-56601, and by the American Heart Association, New York Affiliate, grants 0020152T and 99-30291T. We thank Jennifer Brown and Chiara Kimmel for assistance.

1. Maines, M.D. 1997. The heme oxygenase system: a regulator of second messenger gases. Annu. Rev. Pharmacol. Toxicol. 37:517-554.

2. Wang, R. 1998. Resurgence of carbon monoxide: an endogenous gaseous vasorelaxing factor. Can. J. Physiol. Pharmacol. 76:1-15.

3. Ryter, S.W., and Tyrrel, R.M. 2000. The heme synthesis and degradation pathways: role in oxidant sensitivity. Free Radic. Biol. Med. 28:289-309.

4. Morita, T., Perrella, M.A., Lee, M.E., and Kourembanas, S. 1995. Smooth muscle cell-derived carbon monoxide is a regulator of vascular cGMP. Proc. Natl. Acad. Sci. USA. 92:1475-1479.

5. Christodoulides, N., Durante, W., Kroll, M.H., and Schafer, A.I. 1995 Vascular smooth muscle cell heme oxygenases generate guanylyl cyclasestimulatory carbon monoxide. Circulation. 91:2306-2309.
6. Wang, R., Wu, L., and Wang, Z. 1997. The direct effect of carbon monoxide on $\mathrm{K}_{\mathrm{Ca}}$ channels in vascular smooth muscle cells. Pflugers Arch. 434:285-291.

7. Morita, T., and Kourembanas, S. 1995. Endothelial cell expression of vasoconstrictors and growth factors is regulated by smooth muscle cellderived carbon monoxide. J. Clin. Invest. 96:2676-2682.

8. Ishizaka, N., et al. 1994. Angiotensin II-induced hypertension increases heme oxygenase-1 expression in rat aorta. Circulation. 96:1923-1929.

9. Sammut, I.A., et al. 1998. Carbon monoxide is a major contributor to the regulation of vascular tone in aortas expressing high levels of haeme oxygenase-1. Br. J. Pharmacol. 125:1437-1444.

10. Kozma, F., et al. 1999. Contribution of endogenous carbon monoxide to regulation of diameter in resistance vessels. Am. J. Physiol. Regul. Integr. Comp. Physiol. 276:R1087-R1094.

11. Kozma, F., Johnson, R.A., and Nasjletti, A. 1997. Role of carbon monoxide in heme-induced vasodilation. Eur. J. Pharmacol. 323:R1-R2.

12. Wang, R., Wang, Z., and Wu, L. 1997. Carbon monoxide-induced vasorelaxation and the underlying mechanisms. Br. J. Pharmacol. 121:927-934.

13. Caudill, T.K., Resta, T.C., Kanagy, N.L., and Walker, B.R. 1998. Role of endothelial carbon monoxide in attenuated vasoreactivity following chronic hypoxia. Am. J. Physiol. Regul. Integr. Comp. Physiol. 275:R1025-R1030.

14. Mulvany, M.J., and Halpern, W. 1977. Contractile properties of small arterial resistance vessels in spontaneously hypertensive and normotensive rats. Circ. Res. 41:19-26.

15. Thorup, C., Jones, C.L., Gross, S.S., Moore, L.C., and Goligorsky, M.S. 1999. Carbon monoxide induces vasodilation and nitric oxide release but suppresses endothelial NOS. Am. J. Physiol. Renal Physiol. 277:F882-F889.

16. Abraham, N.G., and daSilva, J.L. 1998. Different physiological functions of heme oxygenase isoforms in endothelial cells (EC). FASEB J. 12:A323. (Abstr.)

17. Jackson, W.F., and Blair, K.L. 1998. Characterization and function of $\mathrm{Ca}^{2+}$-activated $\mathrm{K}^{+}$channels in arteriolar muscle cells. Am. J. Physiol. Heart Circ. Physiol. 274:H27-H34.

18. Liu, H., Mount, D.B., Nasjletti, A., and Wang, W. 1999. Carbon monoxide (CO) stimulates the apical $70 \mathrm{pS} \mathrm{K}^{+}$channel of the rat thick ascending limb. J. Clin. Invest. 103:963-970.

19. Vreman, H.J., Wong, R.J., Sanesi, C.A., Dennery, P.A., and Stevenson, D.K. 1998. Simultaneous production of carbon monoxide and thiobarbituric acid reactive substances in rat tissue preparations by an iron-ascorbate system. Can. J. Physiol. Pharmacol. 76:1057-1065.

20. Vreman, H.J., Ekstrand, B.C., and Stevenson, D.K. 1993. Selection of metalloporphyrin heme oxygenase inhibitors based on potency and photoreactivity. Pediatr. Res. 33:195-200.

21. Jackson, W.F. 2000. Ion channels and vascular tone. Hypertension. 35:173-178.

22. Brayden, J.E., and Nelson, M.T. 1992. Regulation of arterial tone by activation of calcium-dependent potassium channels. Science. 256:532-535.

23. Sacerdoti, D., et al. 1989. Treatment with tin prevents the development of hypertension in spontaneously hypertensive rats. Science. 243:388-390.

24. Levere, R.D., Martasek, P., Escalante, B., Schwartzman, M.L., and Abraham, N.G. 1990. Effect of heme arginate administration on blood pressure in spontaneously hypertensive rats. J. Clin. Invest. 86:213-219.

25. Johnson, R.A., Lavesa, M., Askari, B., Abraham, N.G., and Nasjletti, A. 1995. A heme oxygenase product, presumably carbon monoxide, mediates a vasodepressor function in rats. Hypertension. 25:166-169.

26. Johnson, R.A., Colombari, E., Colombari, D.S.A., Lavesa, M., and Nasjletti, A. 1997. Role of endogenous carbon monoxide in central regulation of arterial pressure. Hypertension. 30:962-967. 